\title{
Impact of forest disturbance on the structure and composition of vegetation in tropical rainforest of Central Sulawesi, Indonesia
}

\author{
RAMADHANIL PITOPANG ${ }^{\boldsymbol{N}}$ \\ Department of Biology, Faculty of Mathematics and Natural Sciences, Tadulako University. Kampus Bumi Tadulako, Tondo, Palu 94118, Central \\ Sulawesi. Tel. +62-451-422611, Fax.+62-451 422844, ’email: pitopang_64@yahoo.com
}

Manuscript received: 1 October 2012. Revision accepted: 25 October 2012.

\begin{abstract}
Pitopang R. 2012. Impact of forest disturbance on the structure and composition of vegetation in tropical rainforest of Central Sulawesi, Indonesia. Biodiversitas 13: 178-189. We presented the structure and composition of vegetation in four (4) different land use types namely undisturbed primary forest, lightly disturbed primary forest, selectively logged forest, and cacao forest garden in tropical rainforest margin of the Lore Lindu National Park, Central Sulawesi Indonesia. Individually all big trees (dbh $\geq 10 \mathrm{~cm})$ was numbered with tree tags and their position in the plot mapped, crown diameter and dbh measured, whereas trunk as well as total height measured by Vertex. Additionally, overstorey plants $(\mathrm{dbh} 2-9.9 \mathrm{~cm})$ were also surveyed in all land use types. Identification of vouchers and additional herbarium specimens was done in the field as well as at Herbarium Celebense (CEB), Tadulako University, and Nationaal Herbarium of Netherland (L) Leiden branch, the Netherland. The result showed that the structure and composition of vegetation in studied are was different. Tree species richness was decreased from primary undisturbed forest to cacao plantation, whereas tree diversity and its composition were significantly different among four (4) land use types. Palaquium obovatum, Chionanthus laxiflorus, Castanopsis acuminatissima, Lithocarpus celebicus, Canarium hirsutum, Euonymus acuminifolius and Sarcosperma paniculatum being predominant in land use type A, B and C and Coffea robusta, Theobroma cacao, Erythrina subumbrans, Gliricidia sepium, Arenga pinnata, and Syzygium aromaticum in the cacao plantation. At the family level, undisturbed natural forest was dominated by Fagaceae and Sapotaceae disturbed forest by Moraceae, Sapotaceae, Rubiaceae, and agroforestry systems by Sterculiaceae and Fabaceae.
\end{abstract}

Key words: tree diversity, land use types, tropical forest, Lore Lindu National Park, Sulawesi, Indonesia

\section{INTRODUCTION}

Sulawesi which was formerly known as Celebes, is one of the big island in Indonesia. The island is the important island in the Wallacea subregion, situated in the centre of the Indonesian archipelago, between Borneo (Kalimantan) and the Moluccan islands. Van Steenis (1979) revealed that phytogeography of Sulawesi is part of the Malesian floristic unit; its flora is reportedly related to the Philippines, New Guinea, and Borneo and belongs to the Eastern Malesian. The Scientific knowledge of Sulawesi's flora both taxonomically and ecologically is still limited due to lack botanical research and publication on this subject (Bass et al. 1990; Keßler 2002), for example the amount of botanical expedition in Sumatra 20 times than Sulawesi (Veldkamp and Rifai 1977) but Sulawesi has recently been identified as one of the world's biodiversity hotspots, especially rich in species found nowhere else in the world and under major threat from widespread deforestation (Pitopang and Gradstein 2003).

Total species richness and endemism of Sulawesi are comparable to those of Sumatra, Java, Borneo and New Guinea, in spite of the very different geological history of Sulawesi and the greater distance of the island to the mainland (Roos et al. 2004). Whereas the islands of Borneo, Sumatra and Java had terrestrial connections to mainland Asia in the past, Sulawesi was always isolated from these islands as well as from New Guinea by deep maritime straits as shown by Hall (1995) and Moss and Wilson (1998). Approximately $15 \%$ of the known flowering plant species of Sulawesi are endemic (Whitten et al. 1987). Van Balgooy et al. (1996) recognized 933 indigenous plant species on Sulawesi and of these 112 were endemic to the island. Endemism varies among groups, however, and is very high in orchids and palms which total 817 orchid species (128 genera) including 493 endemic ones (Thomas and Schuiteman 2002).

Tropical deforestation has become a major concern for the world community. Whole regions in South and Central America, Africa and Southeast Asia already completely lost their forest or are expected to become deforested in the near future (Jepson et al. 2001; Laurence et al. 2001). Based on recent mapping of the forest cover in Indonesia, Ministry of Forestry (MoF) has revealed that the rate of the deforestation in Indonesia approximately doubled between 1985 and 1997, from less than 1.0 million ha to at least 1.7 million ha each year; whereas Sulawesi lost $20 \%$ of its forest cover in this period (Holmes 2002).

Many studies document the loss of biodiversity caused by modification or clearing of tropical rain forest where Human activity is one of the most direct causes of wild biodiversity loss (WCMC 1992) and may also negatively affect biotic interactions and ecosystem stability (SteffanDewenter and Tscharntke 1999). Introduction of exotic 
species, overexploitation of biological resources, habitat reduction by land use change, pastoral overgrazing, expansion of cultivation, and other human activities are common factors and primary agents contributing to the vast endangerments and extinctions occurring in the past and in the foreseeable future (Kerr and Currie 1995; Pimm et al. 1995; Tilman 1999; Palomares 2001; Raffaello 2001).

Human exploitation also causes major changes in the biodiversity of these forests, even though research on this subject has been limited and results were often controversial (Whitmore and Sayer 1992; Turner 1996; Kessler 2005). Some studies reveal conspicuously reduced species richness in secondary or degraded rainforests (Parthasarathy 1999; Pitopang et al. 2002), even in over 100 years old regrown forest (Turner et al. 1997), local extinction of plants (Benitez-Melvido and Martinez-Ramos 2003) in other studies is increased (Kappelle 1995; Fujisaka et al. 1998). Area size is a crucial factor

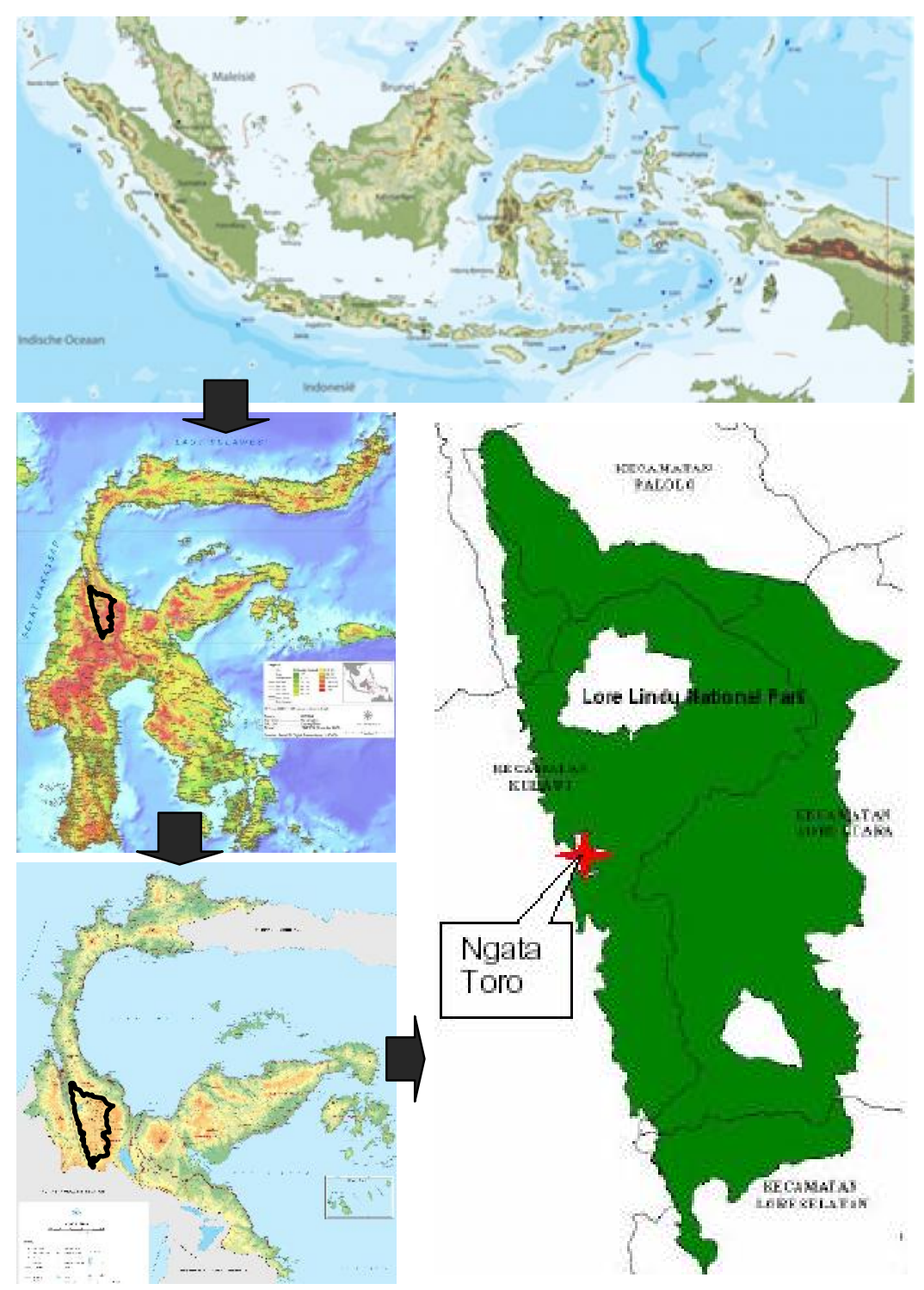

Figure 1. Map of study area, Ngata Toro at the western margin of the Lore Lindu National Park, Central Sulawesi, Indonesia determining the changes in biodiversity due to human impact. Loss of diversity generally decreases when larger areas are considered; therefore the impact of human activities on plant diversity thus must be interpreted with caution (Mooney et al. 1995).

This research focused on the structure and composition of four land use types differing use intensity at the Lore Lindu National Park. The main objective was to determine the taxonomic composition and forest structure of four land use types.

\section{MATERIALS AND METHODS}

\section{Study sites}

The study area was located in the surroundings of Toro, a village at the western margin of Lore Lindu NP about 100 $\mathrm{km}$ south of Palu, the Capital of Central Sulawesi (Figure 1). The data of research was collected from August 2007-March 2009. Detailed information on the climate and soil conditions of this part of Central Sulawesi is not yet available (see Whitten et al. 1987). Gravenhorst et al. (2005) reported that mean annual rainfall in the study area is varied from 1,500 and 3,000 mm, mean relative humidity is $85.17 \%$, monthly mean temperature is $23.40^{\circ} \mathrm{C}$. Administratively, this village belong to Kulawi sub-district, Donggala District. This village is accessible by car, truck, motorbike and public car from Palu. As our study area, the margin of the National Park is characterized in many parts by a mosaic of primary forest, primary less disturbed forest, primary more disturbed forest, secondary forests, and several land-use systems with cacao, coffee, maize, and paddy (rice) as the dominating crops (Gerold et al. 2002). The elevation of the selected sites is between $800 \mathrm{~m}$ and 1100 $\mathrm{m}$, therefore covering an altitudinal range that belongs to the submontane forest zone (Whitten et al. 1987).

Tree diversity was studied in four (4) different land use types with four replicates as follows: (i) Land use type A: undisturbed rain forest. (ii) Land use type B: lightly disturbed rain forest. Natural forest with rattan extraction, rattan palm removed. (iii) Land use type $\mathrm{C}$ moderately disturbed rain forest. Selectively logged forest, containing small to medium sized gaps, disturbed ground vegetation and increased abundance of lianas following the selective removal of canopy trees and rattan. (iv) Land use type D; Cacao forest garden, Cacao cultivated under natural shade trees (= remaining forest cover) in the forest margin (Table 1). 
Table 1. Analyses of structural plant diversity; geographic position (measured by GPS Garmin 12), altitude and descriptions of each plot

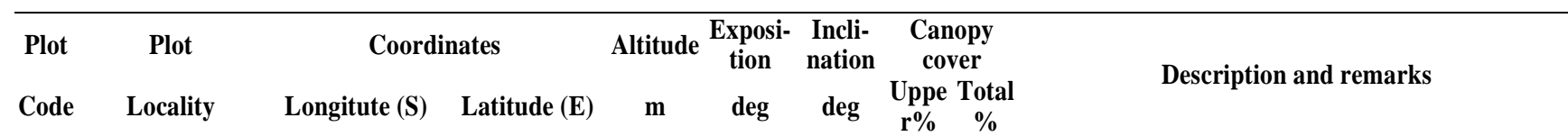

Land use type A (undisturbed rain forest)

A1 Bulu Kalabui $01^{0} 30^{\prime} .589 \quad 120^{\circ} 02^{\prime} .730$

A2 Bulu Lonca

$01^{0} 29^{\prime} .518 \quad 120^{\circ} 01^{\prime} .596 \quad 1080$

ESE

A3 Buku Kalabui

$01^{0} 30^{\prime} .714 \quad 120^{0} 02^{\prime} .750 \quad 950$

A4 Kawumbu

$01^{0} 29^{\prime} .486 \quad 120^{0} 03^{\prime} .054 \quad 1010$

Land use type B ( lightly disturbed rainforest)

B1 Bulu Kuku 01 30’.053 $120^{\circ} 01^{\prime} .653 \quad 1050$

$\begin{array}{ll}\text { B2 } & \text { Bulu Kalabui } \\ & \\ \text { B3 } & \text { Bulu Kuku } \\ & \text { North } \\ \text { B4 } & \text { Kolewuri }\end{array}$

$01^{0} 30^{\prime} .558 \quad 120^{0} 02^{\prime} .967 \quad 840$

$01^{0} 29^{\prime} .400 \quad 120^{\circ} 01^{\prime} .607 \quad 1080$

$01^{0} 29^{\prime} .202 \quad 120^{0} 02^{\prime} .821 \quad 1000$

Land use type $\mathbf{C}$ ( moderately disturbed rain forest)

C1 Bulu Lonca

$01^{0} 29^{\prime} .490 \quad 120^{\circ} 01^{\prime} .738 \quad 1000$

C2 Kolewuri

$01^{0} 29^{\prime} .721 \quad 120^{0} 02^{\prime} .802 \quad 990$

C3 Above Dusu Tujuh

$01^{0} 30^{\prime} .441 \quad 120^{0} 01^{\prime} .373 \quad 1000$ 30

C4 Bulu Kamonua

$01^{0} 22^{\prime} .525$

12

$120^{0} 02^{\prime} .170 \quad 1040$

Land use type $D$ ( Cacao forest garden)

D1 Foot of Lonca $\quad 01^{0} 29^{\prime} .649 \quad 120^{0} 02^{\prime} .134 \quad 840$

D2 Kaha

D3 Kauboga

10

$30-35 \quad 35-$ 40

D4 Foot of Bulu Kalabui $\begin{array}{lll}01^{0} 30^{\prime} .072 & 120^{0} 01^{\prime} .761 & 920 \\ 01^{0} 29^{\prime} .900 & 120^{0} 01^{\prime} .821 & 840\end{array}$

$01^{0} 31.047^{\prime} \quad 120^{0} 01^{\prime} .986 \quad 815$
200
SE

W

20

280

$<25 \quad 75$

$90 \quad 30-40 \quad 60$

70

ESE

25

30

270 200

30

30

$20-40 \quad 30$

80 Many large trees; on eastern slope of Bulu Kalabui but close to ridge; very sparse understorey and variable exposition

75 Many large trees are reaching a height of approximately $35 \mathrm{~m}$, rattan dominating understory, bamboo on lower edge

80 Understory rattan dominated; fairly gentle slope; more slender and lower trees than other plots, even canopy structure; very close to ridge

80 Single large trees are reaching a height of approximately $35 \mathrm{~m}$. Probably colluvium due to variable slope and micro relief. Large rocks on the soil surface. Spring inside plot, canopy very heterogeneous with some extremely large figs, understory relatively dense

85 One of the highest plots. Very dense understorey with much Pandanus; steep and large tree fall gap on lower edge; some smaller gaps already detectable

60- Natural forest with very sparse understorey,

70 close to open plantation for precipitation gauge

$30 \quad 60-80$ Highest and tallest B type. Variable understorey with obvious timber and rotan extraction

80 Steep with light understorey. Fairly moist with tall and slender trees but only little rotan

60 One large older treefall gap and smaller gaps from extracted timber. Variable relief and understorey

60 There are some big tree such as Anthocephalus $\mathrm{sp}$, Pterospermum sp, variable in relief, dense understory with also treefall gaps and moist soil

60 Soil very rocky and dry. On upper slope below clear cut (precipitation gauge?); Understorey dense, extremely steep and far from Toro core area

60 Evenly spaced gaps from timber extraction, understorey not too dense, little rattan

30 Owned by Pak Berwin; worst plot, large gap on lower side without cocoa; steep slope beneath plot towards creek with secondary vegetation. Sparsely spread cocoa, high degree of grass cover, few shade trees, very steep. Northern border transition into E-type plantation.

50 Owned by Pak Abia; flattest type at highest elevation; one large gap of shade trees in center, trees very tall and at upper boundary; variable ground cover

65 Owned by Pak Penga; evenly spaced cocoa trees with few gaps and partly dense herbal undergrowth on even slope. Situated on lower edge of forest. Nearby opening as chance for precipitation gauge

75 Owned by Pak Ambi; steep with thick leaf litter layer and very little herbal undergrowth, highest shade tree cover with small gaps (some shade trees already ringed, some planted or secondary?) cocoa densely planted $(<80 \%)$ especially on lower slope 


\section{Sampling protocol}

Plots size and sampling designed according to standardized protocols (Wright et al. 1997; Milliken 1998; Srinivas and Parthasarathy 2000; Kessler et al. 2005; Small et al. 2004). Plot size was determined by the minimum area curve (Suryanegara and Wirawan, 1986) and was 50 x 50 $m$ with four (4) replicates. Each plot was subdivided into 25 subplots of $10 \times 10 \mathrm{~m}^{2}$ each and all trees $\mathrm{dbh} \geq 10 \mathrm{~cm}$ were recorded. In these subplots (recording units), individually all big trees $(\mathrm{dbh} \geq 10 \mathrm{~cm})$ was numbered with aluminum tags and their position in the plot mapped, crown base crown diameter and dbh measured, and trunk as well as total height estimated. Furthermore, profile diagram of forest both vertical and horizontal was made by using "Hand drawing methods" (Laumonier 1997).

All recognizable morphospecies of trees were collected in sets of at least seven duplicates. Plant collecting was according to the "Schweinfurth method" (Bridson and Forman 1999). Additional voucher specimens of plant material with flowers or fruits were collected for identification purposes. Processing of the specimens was conducted at Herbarium Celebense (CEB), University of Tadulako, Palu. Identification was done in the field, in CEB, and the Herbarium Bogoriense (BO), Bogor. Vouchers were deposited in CEB, with duplicates in BO, GOET, L and BIOT.

\section{Data analyses}

Basal Area (BA), Relative Density (RD), Relative Frequency (RF), Relative Dominance (RDo.), and importance value indices (IVI) were calculated and analyzed according to the formulae Dumbois-Muller and Ellenberg (Soerianegara and Indrawan 1988; Setiadi et al. 2001).

Basal area $\left(\mathrm{m}^{2}\right)$ is the area occupied by a cross-section of stem at breast height $(1.3 \mathrm{~m})=\left[3.14 \mathrm{x}(\mathrm{dbh} / 2)^{2}\right]$

Absolute values so obtained may be transcribed to relative values:

$\begin{array}{ll}\text { Relative density }(\%) & \begin{array}{l}\text { No. of individuals of a species } \\ = \\ \text { Total no. of individuals in sample }\end{array}\end{array}$

$$
\begin{aligned}
& \text { Basal area of a species } \\
& \text { Relative dominance }(\%) \text { = ------------------------- X } 100 \\
& \text { Total basal area in sample }
\end{aligned}
$$$$
\text { Relative frequency }(\%) \quad \frac{\text { Sampling units containing a species }}{\text { Sum of all frequencies }}
$$

Importance Value Index (IVI) for a species is the sum of its relative density, relative dominance, and relative frequency (Soerianegara and Indrawan 1988; Setiadi et al. 2001).

\section{RESULTS AND DISCUSSION}

\section{Species diversity}

Statistically, the averages of number of species, genera, families, Shanon diversity index (H'), native species, timber tree, stem and basal area of tree did not differ among land use type $\mathrm{A}, \mathrm{B}$ and $\mathrm{C}$ but was significantly different with $\mathrm{D}$. The mean species number of tree was highest in land use type B $(58.0 \pm 8)$, followed by land use type A $(55.8 \pm 5.5)$ and type C (48.3 \pm 4.0$)$. Cacao plantations, however, had significantly lower species numbers, with $20.8 \pm 7.8$ tree species in cacao forest gardens.

Roughly one third of the tree species in the forest plots (15-20 spp.) were of economic importance as commercial timber trees; of these, 4-5 were major timber species and the rest minor ones. Timber diversity was little affected by moderate human use of the forest but was significantly reduced in cacao forest gardens and dropped to near zero in cacao plantations.

\section{Taxonomic composition}

Tree species at land use type A are mainly dominated by Palaquium quercifolium (Sapotaceae) and followed by Castanopsis acuminatissima and Lithocarpus celebicus (both Fagaceae), Ficus trachypison, Chionanthus laxiflorus (Oleaceae) and Dysoxylum densiflorum (Meliaceae), Aglaia argentea (Meliaceae), Horsfieldia costulata (Myristicaceae), Meliosma sumatrana (Sabiaceae), and Dysoxylum alliaceum (Meliaceae). Sapling species are presented by Capparis pubiflora (Capparidaceae), Castanopsis accuminatisima, Horsfieldia costulata, Ardisia celebica etc At the family level the forest was dominated by Fagaceae, Sapotaceae, Meliaceae and Lauraceae. At the land use type B tree species mostly dominated by Neonauclea intercontinentalis, Palaquium quercifolium, $P$. obovatum, Pandanus sarasinorum, Meliosma sumatrana etc. Whereas, sapling species is dominated by Pandanus sarasinorum, Pinanga aurantiaca, Horsfieldia costulata, Areca vestiaria etc. The predominant species in moderately disturbed forest (type C) were Oreocnide rubescens (Urticaceae), Castanopsis accuminatisima, Lithocarpus celebicus, Pandanus sarasinorum, Neonuclea intercontinentalis and Canarium hirsutum (Burseraceae). Sapling species are Lithocarpus celebicus, Oreocnide rubescens, Castanopsis accuminatisima, Dysoxylum nutans, Dysoxylum alliaceum etc.

Tree species in cacao forest garden (type D) mainly represented by Theobroma cacao (Sterculiaceae), Coffea robusta (Rubiaceae.), Turpinia sphaerocarpa (Staphyliaceae), Horsfieldia costulata (Myristicaceae), Arenga pinnata (Arecaceae), Meliosma sumatrana, Melicope cf. confusa (Rutaceae) and Oreocnide rubescens.

At the family level, the taxonomic composition of the habitat types showed major differences. Undisturbed natural forest (land use type A) was dominated by Sapotaceae, Fagaceae, Meliaceae, Lauraceae, Myrtaceae, Moraceae, Rubiaceae, Euphorbiaceae, Arecaceae and Oleaceae while Moraceae, Sapotaceae, Rubiaceae, Euphorbiaceae, Meliaceae, Lauraceae and Annonaceae 
were the most common tree families in disturbed forest (land use types B and C). In the cacao forest garden with moderate use intensity (D) was dominated by Sterculiaceae, Moraceae, Rubiaceae, Staphyleaceae, Euphorbiaceae, Cunoniaceae and Myristicaceae.

\section{Forest structure and profile diagram}

Forest structure and profile diagram of these studied land use types were provided in Figures 2, 3, 4, 5, 6 and 7 The analyses of forest structure revealed considerable differences in canopy height where tree species with height $>30 \mathrm{~m}$ (emergent/top canopy species) was greater at the undisturbed rain forest $(11.22 \%)$ and then followed by land use type B $(8.7 \%)$ and $\mathrm{C}(3.9 \%)$. On the other side, only a few tree species $>30 \mathrm{~m}$ in height at the land use type D $(0.9 \%)$, the middle canopy species (height 20.1-30 m) was higher at land use type B (16.35\%) and C (13.8\%) and followed by A $(11.11 \%)$, D $(7.4 \%)$. Contrary to the top canopy species, the undergrowth species (<10 $\mathrm{m}$ in height) was lower at the land use type A (undisturbed rain forest) and gradually increased from type B to D. The greater tree height in undisturbed rain forest (type A) and type B reflect that many originally top canopy trees persisted in these land use type.

At the land use type A (undisturbed natural rain forest), we recorded some top canopy tree species (with $>30 \mathrm{~m}$ in height) such as Palaquium quercifolium, Palaquium obovatum, Castanopsis accuminatisima, Lithocarpus celebicus, Bischofia javanica, Octomeles sumatrana, Cinnamomum parthenoxylon, Pangium edule, Pterospermum celebicum, Aglaia argentea, Dysoxylum sp, Chionanthus ramiflorus, Ficus sp. and Polyscias nodosa. Palaquium quercifolium is one of tree species widely distributed at the land use type $\mathrm{A}, \mathrm{B}$ and $\mathrm{C}$ which several individuals of this species can be reach up to $40 \mathrm{~m}$ in height.

At the land use type B (lightly disturbed forest) recorded the other top canopy species such as Neonuclea intercontinentalis, Artocarpus elasticus, Elmerrillia ovalis, and Magnolia champaca. Contrary to two forest types as mentioned before that there was no any emergent/ top canopy tree species founded at the land use type C (moderate use intensity), but only Palaquium quercifolium, Castanopsis accuminatisima, Canarium hirsutum, and a strangler Ficus sp with height not more than $30 \mathrm{~m}$.

The middle canopy species $(>20 \mathrm{dbh}<30 \mathrm{~m}$ ) which found at the forests (type A, B and C) are mostly presented by Artocarpus vriesiana, Cryptocarya crassinerviopsis, Knema celebica, Goniothalamus brevicuspis, Aglaia argentea, Horsfieldia costulata, Chionanthus laxiflorus, Semecarpus forstenii, Sarcosperma paniculata, Litsea formanii, Castanopsis accuminatisima, Syzygium accuminatisima, Dysoxylum alliaceum, Pandanus polycephalus, Litsea densiflora, Trema orientalis, Broussonetia papyrifera and Mangifera foetida, Gironniera subaequalis, Astronia macrophylla, Ficus miquelii, Nauclea ventricosa, Acer laurinum, Santiria laevigata, Lithocarpus celebicus and Dracontomelon mangiferum.

The lower canopy species were mainly composed by Orophea celebica, Mitrephora celebica, Baccaurea tetrandra, Goniothalamus brevicuspis, Meliosma sumatrana, Gnetum gnemon, Siphonodon celastrineus, Antidesma celebica, Dracaena arborea, Dracaena angustifolia, Aglaia silvestris, Geunsia sp., Sterculia oblongata, Macadamia hildebrandii, Goniothalamus macrophyllus, Arenga pinnata, Picrasma javanica, Calophyllum soulatrii and Macaranga hispida.
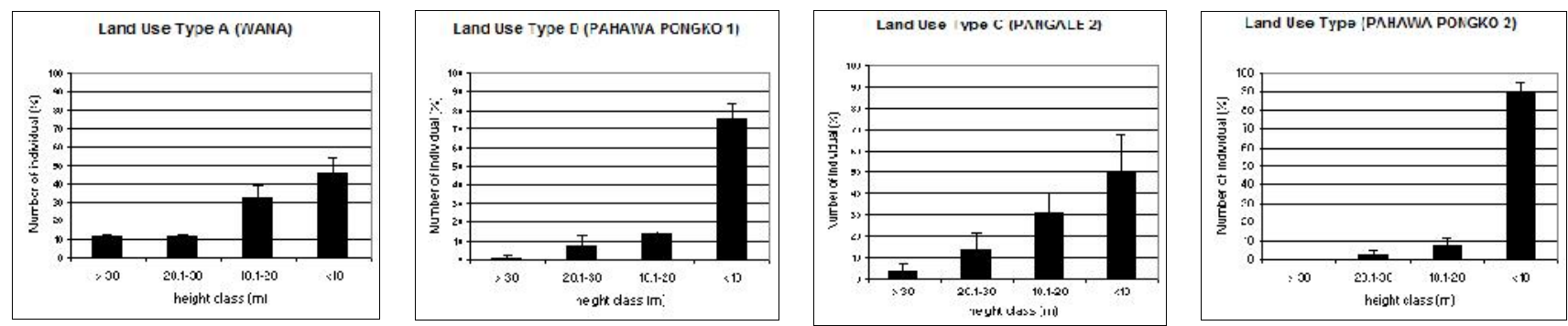

Figure 2. Relative distribution of height class among trees in the four studied Land use types. Error bars indicated + standard error. Notes: $>30 \mathrm{~m}=$ Top canopy species $20.1-30 \mathrm{~m}=$ meddle canopy species, $10.1-20 \mathrm{~m}=$ lower canopy species, $<10 \mathrm{~m}=$ undergrowth species.
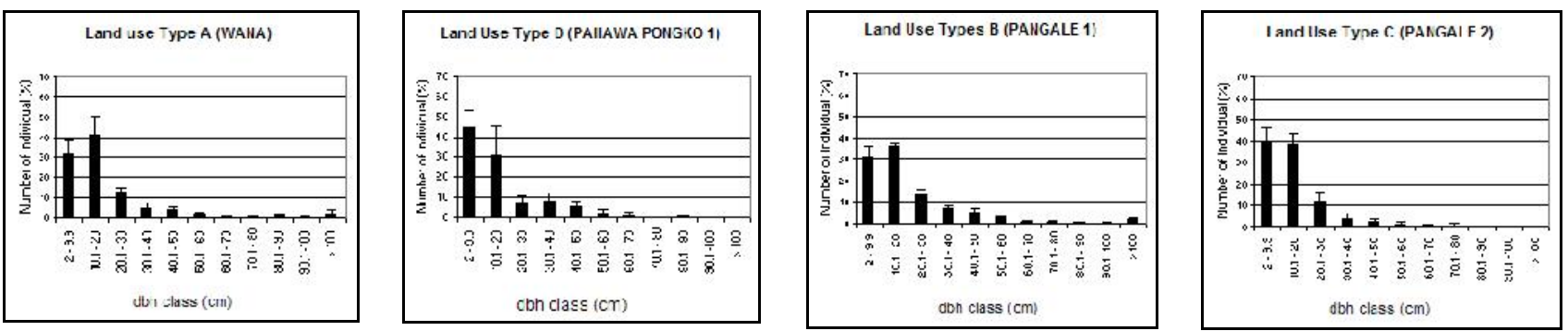

Figure 3.Relative distribution of diameter class among trees in the six studied land use types. Error bars indicated \pm standard error. 


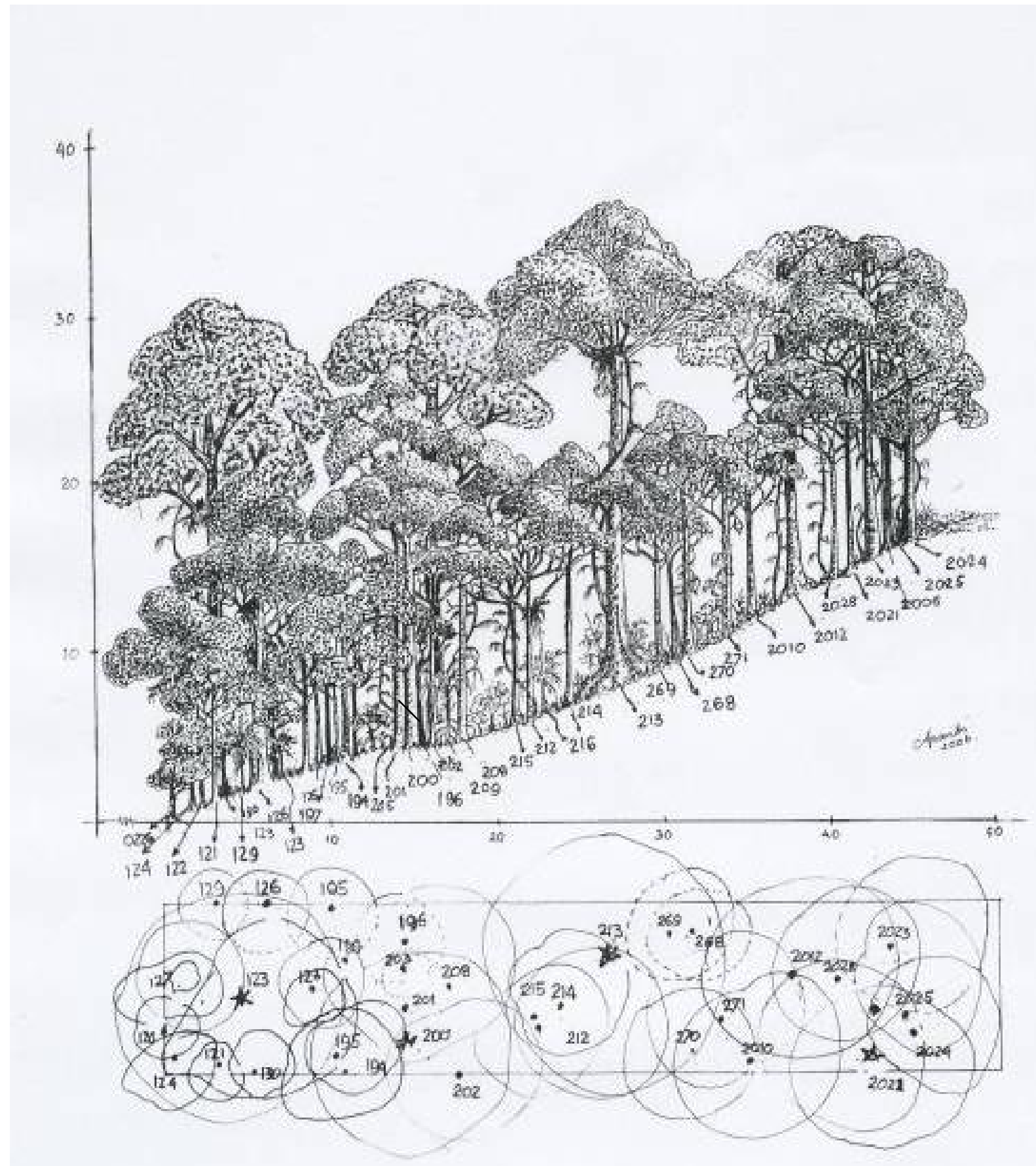

Figure 4. Profile diagram of land use type A (presented by column 5A to 5E of plot A2). Goniothalamus brevicuspis (122), Palaquium quercifolium (200, 201, 208), Beilschmiedia gigantocarpa (123), Baccaurea tetrandra (124), Meliosma sumatrana (125), Antidesma celebicum (126), Semecarpus forstenii (127, 194, 205, 2012, 2022), Macadamia hildebrandii (128), Myristica kjellbergii (129, 215, 217), Pinanga aurantiaca (130,132, 216), Arytera littoralis (131), Castanopsis accuminatisima (121, 213, 214, 2025, 2026), Artocarpus vriesiana (196), Litsea sp (197), Pometia pinnata (198), Dysoxylum parasiticum (199), Chionanthus laxiflorus (202), Horsfieldia costulata (203, 210, 268), Ficus sp (204, 270), Ficus variegata (207), Pandanus lauterbachii (209), Litsea ferruginea (211), Sterculia longifolia (212), Ardisia celebica (218), Elaeocarpus sp (269), Calophyllum soulatrii (271), Litsea formanii (2021), Pisonia umbellifera (2028), Aglaia sp (2024). 


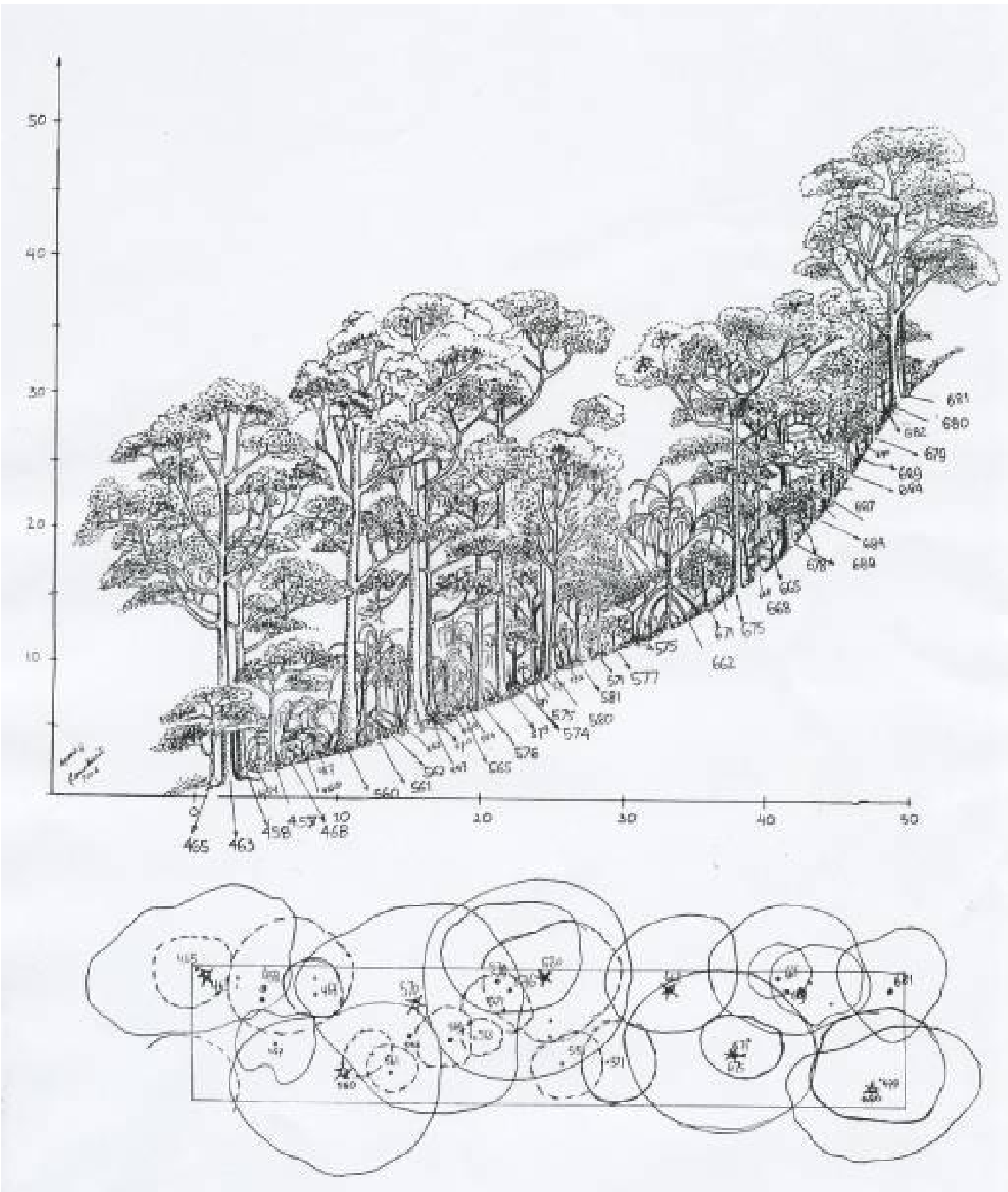

Figure 5. Profile diagram of land use type B (presented by column 5A to 5E of plot B1 at Bulu kuku). Elaeocarpus angustifolius ( 454, 577, 663, 670, 671, 674, 680, 685), Garcinia dulcis (455,575), Antidesma stipulare (457), Chionanthus laxiflorus (458), Pterospermum celebicum (459), Macaranga tanarius (460, 461, 462, 682, 683), Sterculia oblongata (464), Horsfieldia costulata (465, 466, 568, 687), Pandanus sarasinorum (467, 468, 469, 561, 562, 565, 566, 569, 662, 688), Koordersiodendron pinnatum (560), Neonauclea lanceolata (563), Elmerrillia ovalis (564), Artocarpus vriesiana (567), Ficus sp (570,676), Meliosma sumatrana (571, 574), Dysoxylum alliaceum (576, 580, 665, 669), Goniothalamus brevicuspis (578), Aglaia silvestris (579), Dracaena angustifolia (581), Litsea formanii (664, 668, 686), Litsea oppositifolia (666), Gouia sp. (673), Neonauclea intercontinentalis (677), Picrasma javanica (678), Baccaurea tetrandra (679), Polyalthia glauca (681), Dehaasia celebica (689) and Litsea ferruginea $(668,690)$. 


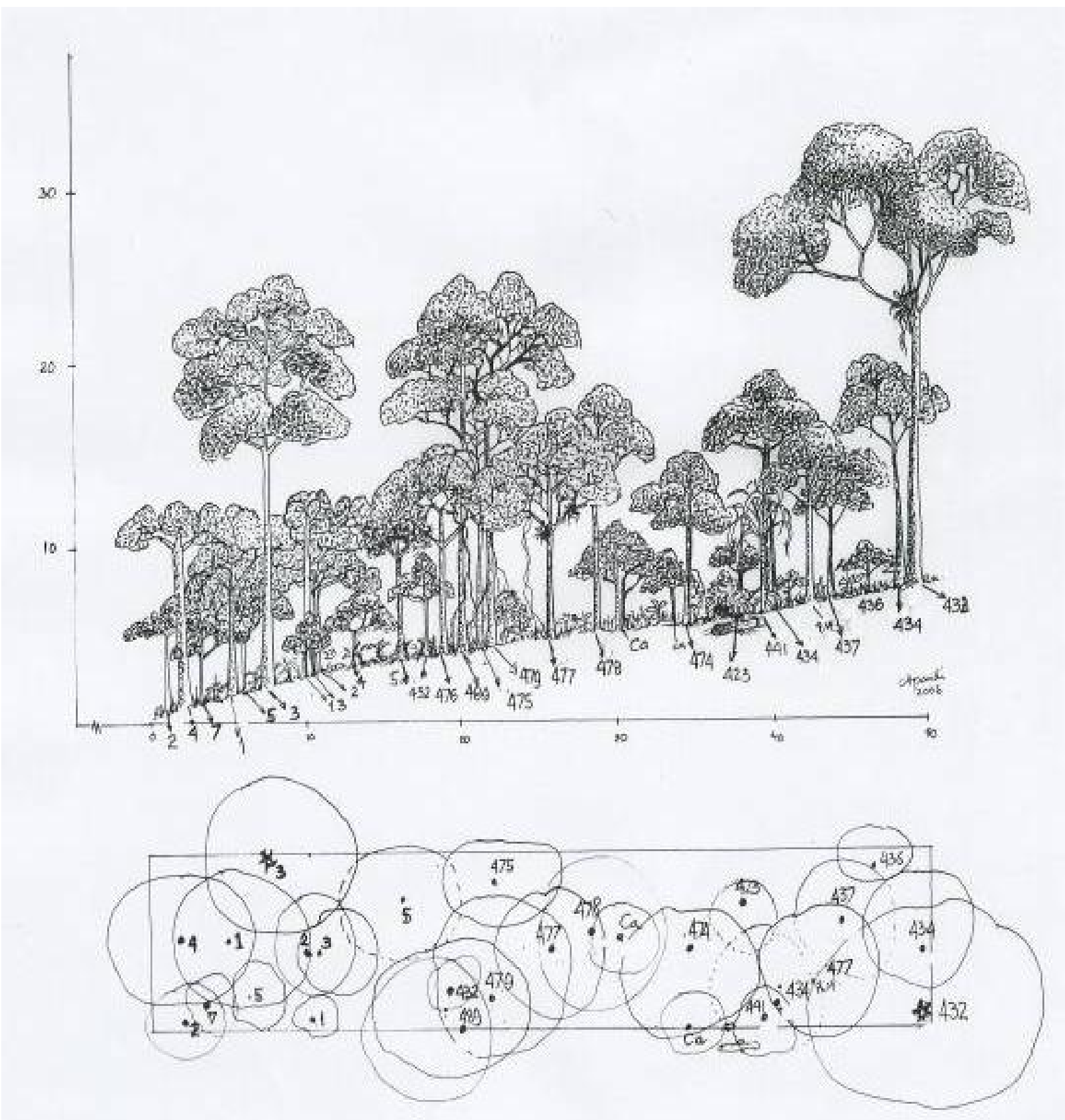

Figure 6. Profile diagram of land use type $\mathrm{C}$ (presented by column $2 \mathrm{~A}$ to $2 \mathrm{E}$ of plot $\mathrm{C} 4)$ ). Macadamia hildebrandii (2A-1), Aglaia exelca (2A-2), Cryptocarya crassinerviopsis (2A-3, 2B-2), Mitrephora celebica (2A-4, 478), Aglaia silvestris (2A-5), Lithocarpus celebicus (2A-6, 2A-9, 2A-12, 2A-13), 491, 492, 493), Litsea albayana (2B-1), Dysoxylum alliaceum (2B-4, 6, 7, 479), Acer laurinum (2B-5), Castanopsis accuminatisima (476, 477, 475, 494, 495, 496), Elaeocarpus sp (490), Horsfieldia costulata (474), Pandanus sarasinorum (441), Sterculia oblongata (432), Pisonia umbellifera (436), Phaleria costata (487), Picrasma javanica (438). 


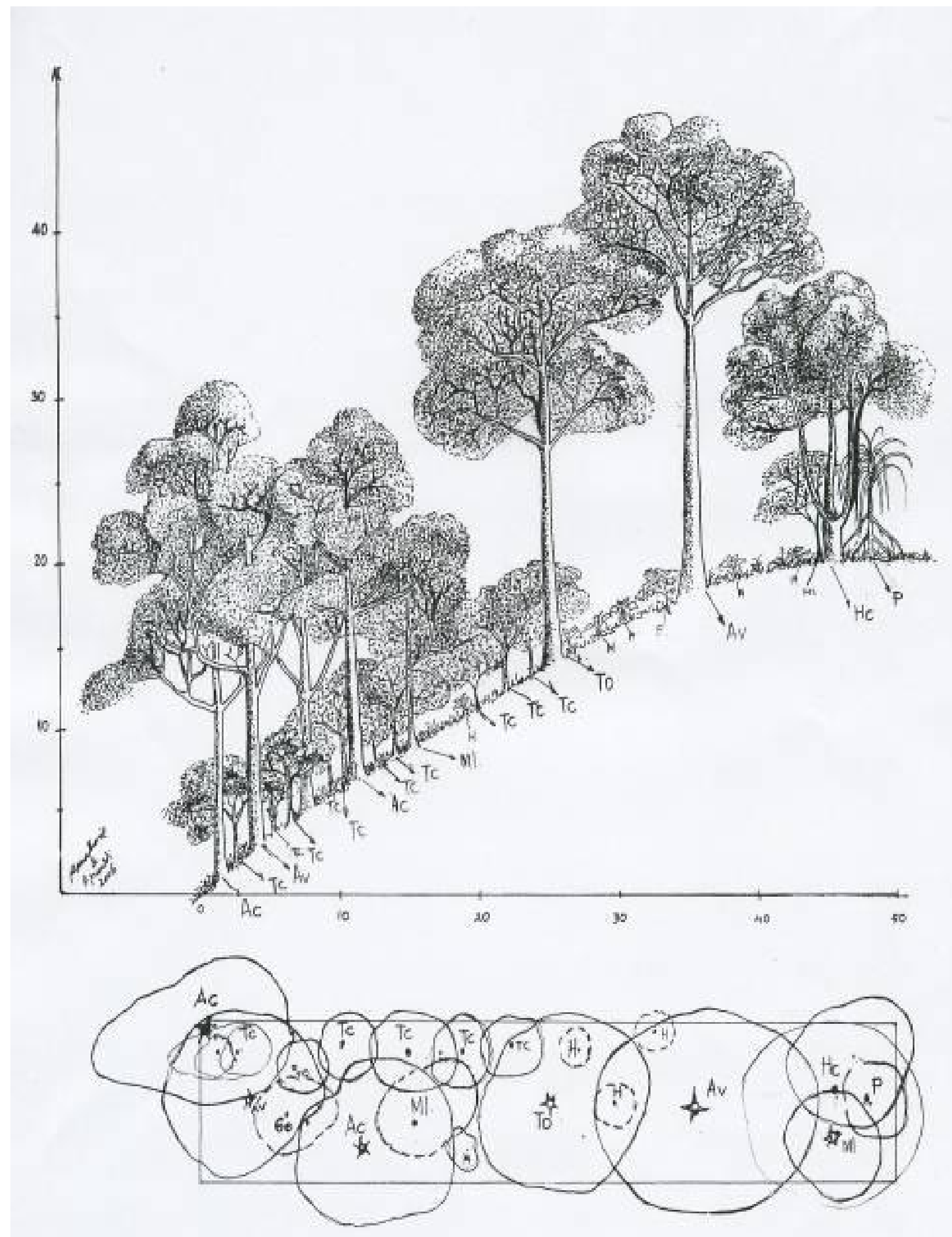

Figure 7. Profile diagram of land use type $\mathrm{D}$ which is presented by column $1 \mathrm{~A}$ to $1 \mathrm{E}$ of plot $\mathrm{D} 4$. Ae $=$ Artocarpus elasticus, $\mathrm{Tc}=$ Theobroma cacao, $\mathrm{Av}=$ Artocarpus vriesiana, $\mathrm{Ge}=$ Geunsia $\mathrm{sp} ., \mathrm{Cr}=$ Coffea robusta, $\mathrm{Ml}=$ Melicope latifolia, $\mathrm{To}=$ Trema orientalis, $\mathrm{Ap}=$ Aphanamixis polystachya, $\mathrm{Da}=$ Dracaena arborea, $\mathrm{Hc}=$ Horsfieldia costulata . 
The small tree/ treelet or undergrowth species $(<10 \mathrm{~cm}$ in height) are composed by Timonius minahassae, Ardisia celebica, Dehaasia celebica, Pinanga caesea, Areca vestiaria, Pinanga aurantifolia, Caryota mytis, Oreocnide rubescens, Dendrocnide stimulant, Dysoxylum nutans, Antidesma stipulare, Lasianthus sp, Arenga undulatifolia, Eurya accuminata, Capparis pubiflora, Ficus gul, Garcinia parviflora, Fagraea racemosa, Tabernaemontana sphaerocarpa, Euonymus javanicus, Homalium javanicum and one tree fern species is Cyathea amboinensis.

In contrast to the land use type $\mathrm{A}$, We were not found any emergent/top canopy species at three cacao plantations. For example, at the land use type D (cacao cultivated under natural shade trees) there were only some big tree species such as Turpinia sphaerocarpa, Trema orientalis, Artocarpus teysmanii, Artocarpus vriesiana, Bischofia javanica, Ficus variegata, Astronia macrophylla and Lithocarpus celebicus but they can not reach more than 30 $\mathrm{m}$ in height.

\section{Discussion}

The analyses of forest structure revealed considerable differences in canopy height (Figure 2 and 3) where tree species with height $>30 \mathrm{~m}$ (emergent/top canopy species) was greater at the undisturbed rain forest $(11.22 \%)$ and then followed by land use type B (8.7\%) and C (3.9\%). Structure and composition of Sulawesi's forest is rather different to other islands (Keßler 2002). The investigated undisturbed rain forests around Toro, the emergent tree species were composed by Palaquium quercifolium, Palaquium obovatum, Castanopsis accuminatisima, Lithocarpus celebicus, Bischofia javanica, Octomeles sumatrana, Pangium edule, Pterospermum celebicum, Aglaia argentea, Chionanthus ramiflorus, and Polyscias nodosa. Laumonier (1997) reported the emergent tree species in the lowland forest of Jambi (Sumatra) mainly represented by fifteen dipterocarp species, three Anacardiaceae species and one species of Apocynaceae. Some of them are Anisoptera costata, Anisoptera laevis, Anisoptera marginata, Dipterocarpus crinitus, Hopea dryobalanoides, Shorea acuminate, Shorea ovalis, Mangifera rigida, Mangifera torquenda, Pentaspadon velutinus and Dyera costulata.

The timber volume was highest in land use type A (undisturbed rain forest) and gradually decreased with increased forest disturbance, and again towards forest gardens and was lowest in plantations. This result indicated that there were many large tree species in the land use type A than other land use type. Some of tree species in land use type A are mainly belong to mayor commercial timber such as Palaquium quercifolium, Palaquium obovatum (Sapotaceae) known as "nyatoh" or "nantu" ("trade name"), Pterospermum celebicum (Sterculiaceae) or "bayur", Dysoxylum spp. (Meliaceae) or "tahiti", Madhuca sp. (Sapotaceae), Aglaia korthalsii, Alstonia scholaris (Apocynaceae) or "pulai", Calophyllum soulatrii (Clusiaceae), beside that there were tree species as minor timber such as Elmerrillia ovalis (Magnoliaceae) or "cempaka", Bischofia javanica (Euphorbiaceae) "balintunga or pepolo", Mussaendopsis celebica (Rubiaceae), Ailanthus sp. (Rubiaceae),
Alseodaphne sp. (Lauraceae), Artocarpus teysmanii or "tea uru", Artocarpus elasticus or "tea" (Moraceae), Artocarpus integer, (Moraceae), Beilschmiedia gigantocarpa (Lauraceae), Canarium hirsutum (Burseraceae), Canarium balsamiferum (Burseraceae), Cinnamomum parthenoxylon (Lauraceae), Cryptocarya crassinerviopsis (Lauraceae), Lithocarpus grandifolius (Fagaceae), Dracontomelon dao (Anacardiaceae), Fragraea racemosa (Loganiaceae), Gymnacranthera sp. (Myristicaceae), Lithocarpus celebicus (Fagaceae), Litsea spp (Lauraceae), Myristica fatua (Myristicaceae), Octomeles sumatrana (Datiscaceae), Sterculia oblongata (Sterculiaceae), Santiria laevigata (Burseraceae), etc. Generally, the timber tree species was found at the research site of Toro, LLNP mainly belong to the important non Dipterocarp trees (Soerianegara and Lemmens 1993; Lemmens et al. 1995; Sosef et al. 1998). Besides that, both Neonauclea spp and Mussaendopsis celebica (Rubiaceae) "pawa", were two economic tree species with heavy and good in quality which have been used locally for long time by the local people for construction, whereas Cacao, coffee and other fruit trees owned by many families at Toro as their cash income, besides collection of sap from the Arenga pinnata ("aren palm") is an important source of income for some families. The sap is collected in bamboo pole and a single tapped tree can produce up to 6 liters a day. The sap can be drunk directly but more often is boiled down to make palm sugar or fermented to produce palm wine (saguer).

Taxonomically, the investigated forests (types A-C) around Toro were mainly dominated by Palaquium quercifolium, P. obovatum, Castanopsis acuminatissima, Lithocarpus celebicus, and Neonauclea intercontinentalis. According to Keßler et al. (2002) and Keßler (2002) the genus Palaquium is represented by eight species in Sulawesi. Palaquium obovatum is common and widespread throughout Sulawesi but $P$. quercifolium is rare in Sulawesi and was previously only recorded from the southern province. Both Palaquium species appear to be common in Lore Lindu National Park where they form tall trees up to $40 \mathrm{~m}$ high. Castanopsis acuminatissima is common and widespread in Sulawesi and is one of two chestnut species known from the island, the other one being Castanopsis buruana. Lithocarpus celebicus is endemic to Sulawesi and widespread in the island, including Lore Lindu National Park. Neonauclea intercontinentalis, finally, seems to be common in Sulawesi (Keßler et al. 2002) and is one of about 20 timber species of the large family Rubiaceae (ca. 600 genera, 10.000 species) in Sulawesi. Other important timber species of Rubiaceae recorded in the forest near Toro include Anthocephalus macrophyllus and Mussaendopsis celebica. The latter two are endemic species of Sulawesi and are representatives of the eastern Malesian element in the island.

The number of endemic species is different among all land use types where endemic trees were best represented in the three forest types with 6-10 species per plot, and declined strongly in the three cacao agroforestry systems with 0-6 species per plot. This pattern was partly a result of the lower overall native tree diversity in the cacao agroforestry systems. When the percentage of endemic 
species was considered, then the cacao forest gardens did not differ significantly ( $0-20 \%$ endemic species) from the three forest types (10-20\%), and only the two cacao systems with planted trees had significantly reduced percentages of endemic trees (0-13\%). Endemic species are of considerable conservation concern and represent about $15 \%$ of the tree flora of Sulawesi (Keßler et al. 2002). This overall value is in good accordance with the percentages recorded by us at the plot level, with $10-20 \%$ of the native tree species recorded in the three forest types and the cacao forest gardens being endemic to the island. The representation of endemic species declined strongly to 0$13 \%$ in the two types of cacao plantations, however, showing that endemic species are more susceptible to severe habitat disturbances than widespread taxa. This is in accordance with general hypotheses on the vulnerability of endemic plants to habitat modifications (Kruckeberg and Rabinovitz 1985).

Secondary forests, regenerating after clear-felling, were not included in the present study but were treated by Pitopang et al. (2002). These forests stand out by their total lack of large trees and the abundance of thin-stemmed trees. The high richness of trees $\geq 5 \mathrm{~cm}$ in secondary forests showed that this forest type has the potential to recover a considerable richness, if allowed to mature. In terms of taxonomic composition, the abundance of Meliaceae, Lauraceae, and Moraceae appeared to be considerably reduced in secondary forests relative to primary forests, whereas in Euphorbiaceae, Urticaceae and Ulmaceae it was increased. The latter families are typical fast-growing pioneer taxa of early successional stages throughout the tropics (Turner 2001; Slik 1998) that are of little economic interest.

\section{CONCLUSION}

In conclusion, we found that moderate human use of the forest ecosystems by rattan and selected timber extraction did not result in significant decreases of tree biodiversity, but the forest structure and its composition were differ among land use type. Number of endemism of tree species was higher in primary forest and it was strongly reduced to cacao forest garden, although percentage endemism did not decline significantly in cacao forest gardens. Roughly one third of tree species in the forest plots were of economic importance as commercial timber trees; timber diversity was little affected by moderate human use of the forest but was significantly reduced in cacao forest gardens.

\section{ACKNOWLEDGEMENTS}

Fieldwork was kindly supported by Department of National Education Republic of Indonesia through the BPPS Scholarship was provided by Directorate General of Higher Education and Collaborative Research Centre 552 at the University of Gottingen, funded by German Research Foundation (DFG). R. Pitopang expresses his gratitude and appreciation to Prof. Stephan R. Gradstein (Paris Museum, France), H. Sahabuddin Mustapa (RIP), formerly the Rector of Universitas Tadulako Palu. Finally I would like to thank an anonymous reviewer for the critical and suggestion on this manuscript.

\section{REFERENCES}

Baas P, Kalkman K, Geesink R. (eds). 1990. The plant diversity of Malesia. Kluwer, Dordrecht.

Benitez-Malvido J, Martinez-Ramos M. 2003. Impact of forest fragmentation on understorey plant species richness in Amazonia. Conserv Biol 17 (2): 389-400

Bridson D, Forman L. 1999. The Herbarium Handbook. Third edition. Royal Botanic Gardends. Kew, London.

Fujisaka S, Escobar G, Veneklaas GE. 1998. Plant community diversity relative to human land uses in an Amazon forest colony. Biodiv Conserv 7: 41-57.

Gerold G, Fremery M, Leuschner C, Guhardja E. 2002. Land use, nature conservation, and the stability of rainforest margins in Southeast Asia. Storma, Bogor.

Gravenhorst G, Ibroms A, Rauf A et al. (2005) Climatological parameters in the research area-supporting measurements and regionalization. STORMA research report. University of Gottingen, Gottingen.

Hall R. 1995. The plate tectonics of Cenozoic SE Asia and the distribution of land and sea. In: Hall R, Holloway JD (eds.). Biogeography and geological evolution of SE Asia. Backhuys, Leiden

Holmes DA. 2002. Where have all the forest gone? Environment and Social Development East Asia, Pasific region Disccusion paper. The World Bank. Washington D.C.

Jepson P, Jarvie JK, MacKinnon K, Monk KA. 2001. The end for Indonesia's lowland rainforest? Science 292, 859-861

Kappelle M, Kennis PAF, de Vries RAJ. 1995. Changes in diversity along a successional gradient in a Costa Rican upper montane Quercus forest. Biodiv Conserv 4: 10-34.

Kerr JT, Currie DJ. 1995. Effects of human activity on global extinction risk. Conserv Biol 9: 1528-1538.

Kessler M, Keßler PJA, Gradstein SR, Bach K, Schmull M, Pitopang R. 2005. Tree diversity in primary forest and different land use systems in Central Sulawesi, Indonesia. Biodiv Conserv 14: 547-560.

Keßler PJA, Bos MM, Sierra Daza SEC, Willemse LPM, Pitopang R, Gradstein SR. 2002. A checklist of the woody plants of Sulawesi, Indonesia. Blumea, Supplement 14: 1-160.

Keßler PJA. 2002. Tree Flora of Lore Lindu National Park, Central Sulawesi, Indonesia. Storma, Bogor.

Kruckeberg AR, Rabinovitz D. 1985. Biological aspects of endemism in higher plants. Ann Rev Ecol Syst 16: 447-479.

Laumonier Y. 1997. The vegetation and physiography of Sumatra. Kluwer, Dordrecht.

Laurence WF, Cochrane MA, Bergen S, Fearnside PM, Delamonica P. 2001. The future of the Brazillian Amazon. Science 291, 438-836

Lemmens RHMJ, Soerianegara I, Wong WC. (Eds.). 1995. Plant Resources of South East Asia (PROSEA). Timber trees: No. 5 (2). Minor commercial timbers. Backhuys Publisher, Leiden.

Milliken W. 1998. Structure and Composition of one hectare of Central Amazonian Tire Firma Forest. Biotropica 30 (4); 530-537

Mooney HA, Lubchenco J, Dirzo R, Sala OE. 1995. Biodiversity and ecosystem functioning: basic principles. In: Heywood VH, Watson RT. (eds) Global Biodiversity Assessment. Cambridge University Press, Cambridge, UK.

Moss SJ, Wilson MEJ (1998) Biogeographic implications of the Tertiary palaeogeographic evolution of Sulawesi and Borneo. In: Hall R, Holloway JD (eds) Biogeography and Geological Evolution of SE Asia. Backhuys, Leiden.

Palomares F. 2001)Vegetation structure and prey abundance requirements of the Iberian lynx: implications for the design of reserves and corridors. J Appl Ecol 38: 9-18.

Parthasarathy N. 1999. Tree diversity and distribution in undisturbed and human-impacted sites of tropical wet evergreen forest in the southern Wastern Ghats, India. Biodiv Conserv 8: 1365-1381.

Pimm SL, Russell GJ, Gittelman JL, Brooks T. 1995. The future of biodiversity. Science 269: 347-350. 
Pitopang R, Gradstein SR, Guhardja E, Keßler PJA, Wiriadinata H. 2002. Tree composition in secondary forest of Lore Lindu National Park, Central Sulawesi, Indonesia. In: Gerold G, Fremery M, Guhardja E (eds.). Land use, Nature Conservation and the Stability of Rainforest Margins in Southeast Asia. Springer, Berlin.

Pitopang R, Gradstein SR. 2003. Herbarium Celebense (CEB) and its role in supporting research on plant diversity of Sulawesi. Biodiversitas 5: 36-41.

Raffaello C. 2001. Biodiversity in the Balance: Land Use, Nationa Development and Global Welfare. The World Bank, Washington, DC, and University College, London.

Roos MC, Keßler PJA, Gradstein SR, Baas P (2004) Species diversity and endemism of five major Malesian islands: diversity-area relationships. J Biogeogr 31: 1893-1908

Setiadi D, Qoyim I, Muhandiono H. 2001. Guidance for Practica Ecology. Ecology Laboratory. Department of Biology. FMNS, Bogor Agricultural University, Bogor. [Indonesia]

Skole D, Tucker C. 1993. Tropical deforestation and habitat fragmentation in the Amazon: satellite data from 1978 to 1988. Science 260: 19051910

Slik JWF (1998) Three new Malesian species of Mallotus section Hanced (Euphorbiaceae). Blumea 43: 225-232.

Small A, Martin TG, Kitching RL, Wong KM. 2004. Contribution of tree species to he biodiversity of a ha old world rainforest in Brunei, Borneo. Biodiv Conserv 13: 2067-2088.

Soerianegara I, Indrawan A. 1988. Forest Ecology Indonesia. Forest Ecology Laboratory. Faculty of Forestry. Bogor Agricultural University, Bogor. [Indonesia]

Soerianegara I, Lemmens RHMJ (eds.). 1993. Plant Resources of South East Asia (PROSEA). Timber trees: majors commercial timbers. No. 5 (1). Pudoc Scientific Publishers, Wageningen.

Sosef MSM, Hong LT, Prawirohatmojo S (eds.). 1998. Plant Resources of South East Asia (PROSEA). No.5 (2). Timber trees: Lesser-known timbers. Backhuys Publisher, Leiden.
Srinivas V, Parthasaranthy N. 2000. Comparative analyses of tree diversity and dispersion in the tropical lowland evergreen forest of Agumbe, Central Western Ghats, India.c Trop Biodiv 7 (1): 45-60

Steffan-Dewenter I, Tscharntke T. 1999. Effects of habitat isolation on pollinator communities and seed set. Oecologia 121: 432-440.

Thomas S, Schuiteman A. 2002. Orchids of Sulawesi and Maluku, a preliminary catalogue. Lindleyana 17: 1-72.

Tilman D. 1999. Diversity by default. Science 283: 495-496.

Turner IM, Wong YK, Chew PT, bin Ibrahim A. 1997. Tree species richness in primary and old secondary tropical forest in Singapore. Biodiv Conserv 6: 237-543

Turner IM. 1996. Species loss in fragments of tropical rain forests: a review of the evidence. J Appl Ecol 33: 200-209

Turner IM. 2001. The Ecology the Tropical Rainforest. Cambridge University Press, Cambridge, UK

Van Balgooy MMJ, Hovenkamp PH, Welzen PC. 1996. Phytogeography of the Pasific- Floristic and historical distribution pattern in plant. In: Keast A, Miller SA (eds). The origin and evolution of Pasific island biotas. New Guinea to eastern Polynesia; pattern and process. SPB Academic Publishing bv., Amsterdam

Van Steenis CGGJ. 1979. Plant-geography of East Malesia. Bot J Linn Soc 79: 97-178

Veldkamp JFMC, Rifai MA. 1977. Flora Malesiana Bulletin 12 (1-2). Leiden; Rijkherbarium

WCMC [World Conservation and Monitoring Center]. 1992. Global Biodiversity: Status of the Earth's Living Resources. Chapman \& Hall, London.

Whitmore TC, Sayer JA (eds). 1992. Tropical Deforestation and Species extinction. Chapman \& Hall, London.

Whitten AJ, Mustafa M, Henderson GS. 1987. The Ecology of Sulawesi. Gadjah Mada Univ. Press, Yogyakarta.

Wright DD, Jessen JH, Burke P, de Silva Garza HG. 1997. Tree and Liana Enumeration and Diversity on a One-Hectare plot in Papua New Guinea. J. Biotropica 29 (3): 250-260. 